\title{
POLITYKA PIENIĘŻNA NARODOWEGO BANKU POLSKIEGO OD ROKU 1989
}

W opracowaniu przedstawiono politykę pieniężną Narodowego Banku Polskiego w okresie ostatnich dwudziestu kilku lat, począwszy od roku 1989, aż do roku 2012. W tym czasie NBP przeszedł głębokie przeobrażenia, które całkowicie odmieniły jego strukturę, rolę i sposób funkcjonowania, przystosowując go do pełnienia funkcji banku centralnego w gospodarce rynkowej. Wraz z nimi zupełnej zmianie uległa polityka pieniężna, nadążając, czy raczej kreując zmiany w gospodarce kraju, które nastąpiły po wprowadzeniu tzw. planu Balcerowicza. Okres ten można podzielić na dwie części, do roku 1998, czyli przed konstytucyjnym określeniem roli i umocowaniem niezależności NBP, oraz po tym doniosłym wydarzeniu do chwili obecnej.

\section{Działalność NBP w okresie PRL}

Narodowy Bank Polski powstał 2 lutego 1945 r. na podstawie dekretu Krajowej Rady Narodowej, funkcjonując przez pierwszych 45 lat swego istnienia, czyli w zasadzie przez cały czas rządów komunistycznych w Polsce, w modelu tzw. monobanku' ${ }^{1}$, tj. banku centralnego właściwego dla gospodarek państw realnego socjalizmu. Innymi słowy, NBP w tym okresie nigdy nie pełnił roli banku centralnego w rozumieniu standardów gospodarki rynkowej, był podporządkowany doraźnym celom władz, co przekładało się na instrumentalne traktowanie go przez rząd i Ministerstwo Finansów. Rząd decydował o emisji pieniądza, mógł zadłużać się w banku centralnym, złoty był walutą niewymienialną, a sektor bankowy scentralizowany. Biorąc to pod uwagę, Narodowy Bank Polski w żaden sposób nie mógł kształtować i odpowiadać za politykę pieniężną $P R L^{2}$.

1 G. Wójtowicz, A. Wójtowicz, Historia monetarna Polski, Twigger, Warszawa 2003, s. 178.

2 Ibidem. 
Zmiany nastąpiły w 1982 r., kiedy to zmieniono Prawo bankowe i statut NBP, nie szły one jednak zbyt daleko, m.in. osłabiły tylko wpływ Ministerstwa Finansów na bank centralny poprzez wprowadzenie innego sposobu powoływania władz banku. Zmiany te nie wpływały na kwestie zasadnicze, NBP był podporządkowany $\mathrm{w}$ dalszym ciągu polityce gospodarczej rządu ${ }^{3}$.

Głębsze zmiany nastąpiły kilka lat później, w 1989 r. (przygotowania rozpoczęto rok wcześniej, w 1988 r.), NBP zaprzestał wtedy działalności depozytowo-kredytowej, z wyjątkiem obsługi depozytów walutowych ludności, a z 430 oddziałów banku utworzono 9 nowych banków komercyjnych, które przejęły od banku centralnego funkcje depozytowo-kredytowe od dnia od 1 lutego 1989 r. ${ }^{4}$ (koniec zmian strukturalnych nastąpił w 1993 r., z NBP wydzielono kolejny bank - Polski Bank Inwestycyjny, który przejął depozyty walutowe ludności). Rozpoczęto budowę dwupoziomowego systemu bankowego. Trzeba przyznać, że ta reforma nie miała precedensu w całym bloku państw socjalistycznych. Ustawa Prawo bankowe z dnia 31 stycznia 1989 r. określała rolę NBP jako centralnego banku państwa mającego przywilej emisji pieniądza, centralnej instytucji rozliczeniowej, kredytowej i dewizowej, a przede wszystkim zobowiązanego do „W szczególności umacniania pieniądza polskiego” oraz współdziałania w kształtowaniu i realizacji polityki gospodarczej państwa. NBP zyskał kompetencje banku centralnego w rozumieniu wymogów stawianych bankom centralnym w gospodarce rynkowej. Fundamentalnym dokumentem w zakresie polityki pieniężnej banku centralnego były założenia polityki pieniężnej na dany rok kalendarzowy. Projekt założeń był przedkładany przez NBP rządowi oraz Sejmowi, które to instytucje nadawały im kształt ostateczny. NBP nie miał praktycznie wpływu na określanie celu finalnego w postaci rocznej inflacji, decydował o tym minister finansów, który ujawniał go w projekcie ustawy budżetowej ${ }^{5}$. De facto istniał wpływ polityków na działanie NBP, a w efekcie niezależność banku centralnego była niska ${ }^{6}$.

\section{Zmiany systemowe w ramach transformacji ustrojowej}

Z początkiem 1990 r. w Polsce przystąpiono do wdrażania planu Balcerowicza, czyli transformacji ustrojowej, było to przedsięwzięcie bez precedensu w skali

3 Ustawa z dnia 26 lutego 1982 r. o statucie Narodowego Banku Polskiego, DzU nr 7, poz. 57.

4 W. Baka, Transformacja bankowości polskiej w latach 1988-1995. Studium monograficzno-porównawcze, Biblioteka Menedżera i Bankowca, Warszawa 1997, s. 30.

5 P. Szpunar, Polityka pieniężna. Cele i warunki skuteczności, PWE, Warszawa 2000, s. 213.

6 R. Kaszubski, Ewolucja polskiej bankowości centralnej, „Materiały i Studia NBP” 1994, z. 44, s. 65. 
świata. Jednym z kluczowych elementów planu było dokończenie reformy sektora bankowego.

Niezwykle ważnym elementem sprawnego działania systemu bankowego była kontrola jego prawidłowego funkcjonowania, co było istotnym zadaniem NBP, realizowana przez nadzór bankowy oraz politykę licencyjną. Nadzór w początkowym okresie nie był restrykcyjny (zalecenia, opracowywano procedury, normy etc.), a polityka licencyjna miała sprzyjać powstawaniu nowych banków i rozwojowi konkurencji na rynku usług bankowych.

Wprowadzenie dwupoziomowego systemu bankowego spowodowało powstanie międzybankowego rynku pieniężnego, bez którego nie sposób prowadzić polityki pieniężnej metodami rynkowymi. Pierwszy jego segment to rynek depozytów międzybankowych ${ }^{7}$. Dalszy rozwój rynku pieniężnego wymagał usprawnienia zawierania krótkoterminowych transakcji oraz rozliczeń międzybankowych poprzez konsolidację ich rachunków. Rynek międzybankowy rósł na przestrzeni kilku lat, w 1995 r. zakończył się etap rozwoju, a elementem, który zadecydował o jego sprawnym funkcjonowaniu, było powołanie w $1992 \mathrm{r}$. Krajowej Izby Rozliczeniowej (KIR) ${ }^{8}$.

Kolejnym krokiem mającym wzmocnić stabilność sektora bankowego było powołanie do życia w roku 1995 Bankowego Funduszu Gwarancyjnego, którego zadaniem była ochrona depozytów klientów banków oraz finansowanie działań sanacyjnych banków. NBP pełnił tu rolę opiniodawczą w zakresie oceny wniosków składanych przez banki do BFG9. Opisane wyżej działania, podjęte w latach 1991-1995, znacząco przyczyniły się do uniknięcia głębokiego kryzysu w systemie bankowym. W efekcie powstał stabilny system bankowy kontrolowany przez sprawny nadzór bankowy. Działaniami towarzyszącymi było powstanie infrastruktury informacyjnej i informatycznej, nowych zasad księgowości, systemu rozrachunków międzybankowych etc.

Zmiany zaszły też w nadzorze bankowym; wprowadziły je: ustawa o NBP z 1997 r. oraz ustawa Prawo bankowe $\mathrm{z}$ tego samego roku$^{10}$; od 1 stycznia 1998 r. nadzór nad bankami został podporządkowany Komisji Nadzoru Bankowego, której przewodniczył z mocy ustawy prezes NBP, a w jej składzie znaleźli się minister finansów (lub jego delegat), przedstawiciel prezydenta, prezes Bankowego Funduszu Gwarancyjnego, przewodniczący Komisji Papierów Wartościowych i generalny inspektor nadzoru bankowego. Zmianą, która nastąpiła już po okresie transformacji, dotyczyła nadzoru bankowego, bowiem od 1 stycznia 2008 r. wszedł on w struktury nowo powołanej Komisji Nadzoru Finansowego, w której znalazł się Pion Nadzoru Bankowego. W ten

7 R. Kokoszczyński, Współczesna polityka pieniężna w Polsce, PWE, Warszawa 2004, s. 213.

8 Ibidem, s. 214.

9 Raport Roczny NBP 1997, NBP, Warszawa 1998, s. 26-27.

10 Ustawa z dnia 29 sierpnia 1997 r. Prawo bankowe, DzU nr 140, poz. 939. 
sposób nadzór bankowy całkowicie wyszedł ze struktur NBP, przy czym w skład Komisji wchodzą prezes NBP albo jego przedstawiciel.

Ustawa z 1997 r. nie wprowadziła zmian, jeśli chodzi o rolę NBP jako banku państwa, z wyjątkiem braku możliwości finansowania deficytu budżetowego. Pozostałe czynności dotyczą prowadzenia bankowej obsługi budżetu państwa, obrotu skarbowymi papierami wartościowymi, prowadzenia rachunków instytucji państwowych. NBP w dalszym ciągu był agentem dewizowym rządu, pozostał centralną instytucją dewizową - gromadził i zarządzał rezerwami dewizowymi, obsługiwał kredyty zagraniczne zaciągnięte przez rząd. NBP opracował bilans płatniczy oraz stan należności i zobowiązań zagranicznych państwa, opiniował projekty aktów normatywnych z zakresu polityki gospodarczej i bankowej.

W październiku 1998 r. Komitet ds. Przygotowania NBP do Integracji Europejskiej rozpoczął działalność pod kątem koordynacji prac przygotowujących bank centralny do wymogów wynikających z pełnego członkostwa w Unii i dostosowania NBP do funkcjonowania w ramach Europejskiego Systemu Banków Centralnych. Współpraca z Europejskim Bankiem Centralnym została podjęta w lipcu 1999 r. ${ }^{11}$ Dnia 1 maja 2004 r. NBP został członkiem Europejskiego Systemu Banków Centralnych.

W pierwszej dekadzie XXI w. kilkakrotnie dokonywano zmian w ustawach przyjętych w 1997 r. (główna przyczyna to proces harmonizacji polskiego ustawodawstwa z unijnym), pozycja ustrojowa NBP zasadniczo nie została zmieniona.

Reformy w polskim systemie bankowym wynikające z pełnego członkostwa w UE dla NBP oznaczały m.in. istotne umocnienie niezależności banku centralnego, wprowadzenie zakazu finansowania deficytu budżetowego. Zapisy o ustroju NBP znalazły się też w Konstytucji RP z 1997 r., spośród nich najważniejsze to zapewnienie roli centralnego banku państwa NBP z wyłącznym prawem emisji pieniądza oraz ustalania i prowadzenia polityki pieniężnej i odpowiedzialnością za wartość polskiego pieniądza. Dalej, do organów statutowych NBP dodano Radę Polityki Pieniężnej, określono jej skład i zadania, czas trwania kadencji prezesa NBP oraz sposób powoływania i apolityczność tego stanowiska. Statutowym celem NBP stało się , utrzymanie stabilnego poziomu cen przy jednoczesnym wspieraniu polityki gospodarczej rządu, o ile nie ogranicza to podstawowego celu NBP”. Jeśli nowa ustawa potwierdzała dotychczasowe prerogatywy NBP, to utworzenie Rady, ciała kolegialnego, odpowiedzialnego za prowadzenie polityki pieniężnej, było novum. Do 1997 r. decyzje w tym obszarze pozostawały w gestii prezesa NBP (de facto podejmowano je po pozytywnym zaopiniowaniu przez Zarząd NBP). Rozwiązaniem, które godziło wymogi niezależności i demokratycznej kontroli, było powierzenie polityki pieniężnej ciału kolegialnemu.

11 Raport Roczny NBP 1999, NBP, Warszawa 2000, s. 50-51. 
W skład Rady Polityki Pieniężnej wchodzą prezes NBP, który jest jej przewodniczącym, oraz dziewięciu członków. Członkowie Rady powoływani są na 6 lat.

Rada Polityki Pieniężnej ukonstytuowała się 17 lutego 1998 r. $^{12}$, a do jej kompetencji należy:

- ustalanie corocznych założeń polityki pieniężnej i przedkładanie ich do wiadomości Sejmowi wraz z przedłożeniem przez Radę Ministrów projektu ustawy budżetowej,

- składanie Sejmowi sprawozdania z wykonania założeń polityki pieniężnej w ciągu 5 miesięcy od zakończenia roku budżetowego,

- ustalanie wysokości stóp procentowych NBP,

- ustalanie zasad i stopy rezerwy obowiązkowej banków,

- określanie górnych granic zobowiązań wynikających z zaciągania przez NBP pożyczek i kredytów w zagranicznych instytucjach bankowych i finansowych,

- zatwierdzanie planu finansowego NBP oraz sprawozdania z działalności NBP,

- przyjmowanie rocznych sprawozdań finansowych NBP,

- ustalanie zasad operacji otwartego rynku ${ }^{13}$.

\section{Polityka pieniężna banku centralnego w latach 1989-1997}

Zadaniem podstawowym NBP o najwyższym priorytecie po roku 1989 było zdławienie hiperinflacji oraz ciągłe i systematyczne obniżanie inflacji w dynamicznie zmiennym otoczeniu krajowym i międzynarodowym, instytucjonalnym oraz gospodarczym. Warunki zewnętrzne determinowały korygowanie taktyki i strategii prowadzenia polityki pieniężnej. W początkowym okresie funkcjonowania banku jego aktywność cechowała różnorodność działań, m.in. oddziaływanie na poziom cen przez: wpływanie na podaż pieniądza, działania na rzecz stabilizacji kursu, utrzymywanie stóp procentowych na poziomie dającym realną dodatnią stopę oprocentowania depozytów terminowych. NBP wykorzystywał narzędzia ekonomiczne i administracyjne w polityce pieniężnej, począwszy od 1993 r. zaczęły przeważać instrumenty rynkowe ${ }^{14}$.

12 Raport Roczny NBP 1998, NBP, Warszawa 2000, s. 15.

13 Art. 12 ustawy z dnia 31 stycznia 1989 r. o Narodowym Banku Polskim, DzU nr 4, poz. 22.

14 R. Kokoszczyński, op.cit., s. 217, 219, 224. 
Po reformie 1989 r. podstawowymi instrumentami polityki pieniężnej banku centralnego były kredyty refinansowe oraz rezerwa obowiązkowa ${ }^{15}$. Podstawowym źródłem zasilania banków w pieniądz był kredyt refinansowy (udział banków w puli kredytów udzielanych podmiotom gospodarczym był niezwykle wysoki i w $1989 \mathrm{r}$. wynosił 65\%). Czynnikiem nie do pominięcia dla banków było jego oprocentowanie. Elementem niekorzystnie wpływającym na rozwój konkurencji na rynku banków komercyjnych był duży udział kredytu refinansowego w pasywach banków, gdyż przeciwdziałał staraniom o pozyskanie depozytów odludności i przedsiębiorstw ${ }^{16}$. Przebudowa systemu oraz metod refinansowania banków nastąpiła na przełomie lat 80 . i 90., likwidacji uległa większość tytułów do preferencyjnych kredytów i ulg w oprocentowaniu ${ }^{17}$. Kredyt refinansowy został poddany konwersji i zaprzestano bezpośredniego udzielania go bankom.

Środkiem wprowadzonym w celu rozwiązania przejściowych problemów z płynnością był kredyt lombardowy udzielany bankom pod zastaw państwowych papierów wartościowych. Wprowadzono też kredyt redyskontowy, który w założeniach miał przejąć ciężar kredytowania gospodarki w NBP. Oba nowe kredyty, lombardowy i redyskontowy, rozpoczęły wypieranie kredytu refinansowego, a ich oprocentowanie weszło do zestawu instrumentów regulacji rynku pieniężnego, jednak minęło kilka lat, zanim zaczęły odgrywać istotną rolę na rynku ${ }^{18}$. Narzędzia ekonomiczne nie wpływały na zmniejszanie inflacji ze względu na utrzymującą się dużą nadpłynność sektora bankowego, co skłoniło bank centralny do użycia narzędzi administracyjnych. Należały do nich tzw. pułapy kredytowe, które determinowały górną granicę akcji kredytowej banków. Przez pierwsze trzy lata po wejściu w życie ustawy o dwupoziomowym systemie bankowym, do 1992 r. włącznie, NBP ingerując administracyjnie w politykę kredytową banków komercyjnych, narzucał minimalny poziom oprocentowania depozytów i maksymalny poziom oprocentowania kredytów ${ }^{19}$. Podobnie od 1989 r. NBP, chcąc utrzymać podaż pieniądza w zadanym przedziale, często używał innego instrumentu, tj. stopy rezerw obowiązkowych, nie cofając się przed częstym podnoszeniem jej poziomu do maksimum ustawowego, czyli 30\%. Z biegiem czasu, uwzględniwszy negatywny wpływ zmian poziomu rezerw na funkcjonowanie banków komercyjnych, częstość ingerencji zmalała, by w $1994 \mathrm{r}$. powstały nowe zasady naliczania rezerw i wykorzystania ich do bieżących rozliczeń

\footnotetext{
15 Z. Polański, B. Pietrzak, B. Woźniak, System finansowy w Polsce, Wydawnictwo Naukowe PWN, Warszawa 2004, s. 150.

16 P. Wyczański, M. Gołajewska, Polski system bankowy 1990-1994, Fundacja Friedricha Eberta Przedstawicielstwo w Polsce, Warszawa 1995, s. 39.

17 Ustawa z dnia 28 grudnia 1989 r. o uporządkowaniu stosunków kredytowych, DzU nr 74, poz. 440.

18 R. Kokoszczyński, op.cit., s. 216.

19 P. Wyczański, M. Gołajewska, op.cit., s. 53 i n.
} 
pieniężnych wraz z konsolidacją środków zgromadzonych przez banki w NBP. Przyniosło to owoce w postaci zmniejszenia trudności płatniczych banków związanych $\mathrm{z}$ regulowaniem zobowiązań $\mathrm{w}$ rozliczeniach międzybankowych oraz wpłynęło pozytywnie na poprawę płynności systemu bankowego ${ }^{20}$.

Od lipca $1990 \mathrm{r}$. bank centralny rozpoczął stosowanie operacji (przypominających operacje otwartego rynku), które polegały na cotygodniowej aukcyjnej sprzedaży (skupie) krótkoterminowych weksli (bonów pieniężnych NBP). W 1991 r. rząd został zmuszony do finansowania deficytu budżetowego poprzez emisję bonów skarbowych. Ten nowy instrument finansowy oferowany był bankom komercyjnym oraz sektorowi niefinansowemu. Efektem było zastosowanie w 1992 r., na początku w niewielkim zakresie, klasycznych instrumentów oddziaływania na płynność finansową banków komercyjnych - operacji otwartego rynku. Pod koniec 1992 r. pojawiło się zarządzenie prezesa NBP regulujące zasady ich stosowania ${ }^{21}$. W1993 r. powołano Komitet Koordynacji Operacji Otwartego Rynku, jako że operacje otwartego rynku zaczynały odgrywać coraz ważniejszą rolę w ograniczaniu płynności banków oraz - co jest z tym powiązane - kreacji pieniądza i stopy inflacji, a od 1994 r. również kontroli rynkowych stóp procentowych.

W ślad za tymi działaniami diametralnie zmieniła się polityka kursowa. Od $1991 \mathrm{r}$. podstawowe i konkurujące ze sobą cele stanowiły: stymulowanie zdolności eksportowych gospodarki, utrzymanie wzrostu rezerw dewizowych na bezpiecznym poziomie oraz ograniczanie możliwości inflacyjnego wpływu dewaluacji na gospodarkę. W tym samym roku w maju zdewaluowano złotego (z 9500 zł za USD do 11100 zł za USD), a jego kurs usztywniono wobec koszyka pięciu walut: 45\% dolar USA, 35\% marka niemiecka, $10 \%$ funt brytyjski, 5\% frank francuski i pozostałe $5 \%$ frank szwajcarski. Październik 1991 r. przyniósł kolejną zmianę, a mianowicie system pełzającej (codziennej) dewaluacji kursu centralnego NBP wobec koszyka walut, złoty był dewaluowany stosownie do tempa inflacji ${ }^{22}$. Banki komercyjne uzyskały, począwszy od stycznia 1992 r., możliwość swobodnego, choć ograniczonego (wahania kursów dziennych nie większe niż $\pm 2 \%$ od kursu średniego NBP) ustalania kursu złotego w zawieranych przez siebie transakcjach dewizowych ${ }^{23}$. W lutym 1992 r. zdecydowano o skokowej dewaluacji złotego (12\%) z uwagi na pogorszenie sytuacji w polskim handlu zagranicznym. Działania te podjęto w celu powstania międzybankowego rynku walutowego.

\footnotetext{
${ }^{20}$ R. Kokoszczyński, op.cit., s. 213-214.

${ }^{21}$ Zarządzenie Prezesa NBP z grudnia 1992 r. w sprawie Regulaminu aukcyjnego obrotu papierami wartościowymi między NBP a bankami, DzUrz. NBP nr 14, poz. 27.

22 R. Kokoszczyński, op.cit., s. 229.

23 Biuletyn Informacyjny NBP 1992, NBP, Warszawa 1993, s. 30.
} 
W niedługim czasie ewidentne stało się, iż wiele z nowych podmiotów nie radziło sobie w sytuacji wdrażania reform gospodarczych. Zaistniał problem tzw. trudnych kredytów, który dotknął również banki państwowe. Sytuacja była na tyle zła, że znowelizowano Prawo bankowe oraz zaostrzono politykę licencyjną NBP. Kompetencje NBP wzmocniono w 1992 r., a prezes NBP mógł stosować instrumenty rzeczywiście wpływające na banki komercyjne, nadzór bankowy został zaostrzony, wymogi kapitałowe podniesione ${ }^{24}$. Dodatkowo NBP wraz z Ministerstwem Finansów zaangażowany został w proces naprawczy sektora bankowego, co trwało kilka lat i dotyczyło zarówno banków komercyjnych, jak i spółdzielczych, a polegało na wprowadzeniu nowych regulacji ostrożnościowych (normy dopuszczalnego ryzyka walutowego w działalności banków, tworzenie rezerw na aktywa obciążone ryzykiem). Ponadto bank centralny udzielał wsparcia finansowego - kredytami lub zwolnieniami środków rezerwy obowiązkowej, wspierał procesy restrukturyzacji oraz przejmowania słabszych banków przez silniejsze. Liczbowo można to wyrazić następująco: do końca 1997 r. pomyślnie zakończono procesy naprawcze w 17 bankach, w kolejnych 14 kontynuowano je $\mathrm{e}^{25}$.

Członkostwo w Unii Europejskiej stawało się w połowie lat 90. coraz bardziej realne (układ stowarzyszeniowy wszedł w życie w lutym 1994 r.). Polska zobowiązała się w ciągu 10 lat spełnić określone warunki ekonomiczne i prawne pozwalające na uzyskanie pełnego członkostwa w UE. Kraje EWG podpisały w $1992 \mathrm{r}$. Traktat o Unii Europejskiej, zwany Traktatem z Maastricht, w którym zawarto m.in. kryteria z zakresu polityki monetarnej (niska inflacja oraz stopy procentowe) ${ }^{26}$. Postanowienia traktatu przewidywały, że w przyszłej unii Europejski System Banków Centralnych, na który składały się Europejski Bank Centralny oraz narodowe banki centralne, będzie prowadził jednolitą politykę pieniężną.

Choć traktat zakładał strategię antyinflacyjną polityki pieniężnej ESBC, to jednocześnie podkreślał pełną niezależność banku centralnego oraz zobowiązanie dla wszystkich państw członkowskich, by taką autonomię dla swoich banków centralnych zapewniły ${ }^{27}$. Państwa uczestniczące w budowie Unii Gospodarczej i Walutowej zobowiązane były do koordynacji polityki pieniężnej i wzmocnienia współpracy banków centralnych. Kraj przystępujący do UGW powinien spełnić cztery kryteria:

24 Ibidem, s. 22.

25 Raport Roczny NBP 1997, op.cit., s. 27.

26 Kryteria fiskalne: deficyt budżetowy nie mógł przekraczać 3\% PKB, dług publiczny 60\% PKB. Kryteria konwergencji dotyczyły też stabilności cen, kursu walutowego, poziomu długookresowych stóp procentowych, jako punkt odniesienia przyjęto średnią dla tych kategorii w najbardziej stabilnych pod tym względem państwach Unii.

27 L. Oręziak, Unia gospodarcza i walutowa, w: Unia Europejska, red. K. Michałowska-Gorywoda, PWN, Warszawa 1997, s. 268-277. 
wysoki stopień stabilności cen, niewystępowanie nadmiernego deficytu budżetu i długu publicznego, spełnienie kryterium kursu walutowego oraz legitymowanie się trwałym charakterem osiągniętej zbieżności w wyniku udziału kraju członkowskiego w mechanizmie kursowym Europejskiego Systemu Walutowego przez co najmniej 2 lata, „znajdującym odbicie w poziomie długoterminowych stóp procentowych"28. Przyjęcie przez Polskę wspólnej waluty i uczestnictwo w UGW będzie dużym wyzwaniem, również politycznym, wymaga bowiem zmian również w prawodawstwie krajowym, w tym ustawy zasadniczej. Z przystąpieniem do Unii Gospodarczej i Walutowej wiąże się trwałe i długookresowe spełnianie kryteriów konwergencji, pierwszym z nich jest wprowadzenie złotego na 2 lata do ERM II (European Rate - Mechanism II), czyli europejskiego systemu regulowania kursów (będącego modyfikacją ESW), a więc sztywne związanie złotego z euro, przy określeniu wąskiego pasma dopuszczalnych wahań. Po wprowadzeniu euro NBP utraci status narodowej instytucji emisyjnej, a jednocześnie w pełni będzie uczestniczyć w ESBC i nie będzie mógł prowadzić samodzielnej polityki pieniężnej.

Połowa lat 90. przyniosła zmianę polityki kursowej, możliwą do wprowadzenia dzięki wysokiemu poziomowi rezerw dewizowych NBP. Powodem była chęć uelastycznienia i zwiększenia skuteczności działań antyinflacyjnych. Jesienią 1994 r. obniżono tempo miesięcznej dewaluacji kursu centralnego (do 1,2\%), a wiosną $1995 \mathrm{r}$. zwiększono różnicę między kursem kupna i sprzedaży walut przez NBP (z 1\% do 4\%) oraz poszerzono pasmo odchyleń międzybankowego kursu złotego od kursu NBP (do $7 \%)^{29}$. Działania te były możliwe z uwagi na stałą aprecjację złotego ${ }^{30}$. Kurs złotego uległ rewaluacji (o 6\%) na przełomie lat 1995 i 1996, a tempo dewaluacji obniżono do $1 \%$ miesięcznie. System pełzającego pasma (jednoprocentowa stopa dewaluacji z pasmem odchyleń $\pm 7 \%$ ) obowiązywał do $1997 \mathrm{r}^{31}$ Częste interwencje na międzybankowym rynku dewizowym wzmacniały przyjęty mechanizm, a miały miejsce w sytuacjach nadmiernej aprecjacji rynkowego kursu złotego. Podstawowym celem polityki kursowej było ograniczanie tempa narastania deficytu w obrotach bieżących i poprawa efektywności eksportu oraz pogorszenie opłacalności importu, przeciwdziałanie inflacji zeszło na plan dalszy ${ }^{32}$.

\footnotetext{
${ }^{28}$ Ibidem, s. 274.

29 Biuletyn Informacyjny NBP 1994, NBP, Warszawa 1995, s. 27-28.

${ }^{30}$ G. Wójtowicz, Narodowy Bank Polski w okresie transformacji, w: Bankowość centralna od A do Z, red. R. Kokoszczyński, B. Pietrzak, Wydawnictwo NBP, Warszawa 2007, s. 144.

${ }^{31}$ Raport Roczny NBP 1997, op.cit., s. 19-20.

32 Ibidem.
} 
Tabela 1. Inflacja i podaż pieniądza w Polsce w okresie 1989-1997

\begin{tabular}{|l|c|c|}
\hline \multicolumn{1}{|c|}{ Rok } & Inflacja $(\mathrm{w} \%)$ & Przyrost podaży pieniądza $\left(\mathrm{w}\right.$ mld zł) $^{\mathrm{a}}$ \\
\hline 1989 & 251,1 & 10,3 \\
\hline 1990 & 585,8 & 9,0 \\
\hline 1991 & 70,3 & 15,0 \\
\hline 1992 & 43,0 & 14,8 \\
\hline 1993 & 35,3 & 21,4 \\
\hline 1994 & 32,2 & 26,9 \\
\hline 1995 & 27,8 & 30,5 \\
\hline 1996 & 19,9 & 39,8 \\
\hline 1997 & 14,9 & 39,2 \\
\hline
\end{tabular}

${ }^{\mathrm{a}}$ W 1990 r. pieniądz krajowy, od 1991 r. agregat M2.

Źródło: Opracowanie własne na podstawie: R. Kokoszczyński, Współczesna polityka pieniężna w Polsce, PWE, Warszawa 2004, s. 232; http://www.stat.gov.pl/gus/5840_1634_PLK_HTML.htm, dostęp 4.03.2014.

W analizowanym okresie NBP nie mógł prowadzić w pełni skutecznej polityki pieniężnej, szczególnie w pierwszym etapie transformacji, dotyczyło to głównie kontroli podaży pieniądza (patrz tabela 1). Miało na to wpływ wiele czynników, przede wszystkim niezbyt dobra koordynacja polityki monetarnej oraz polityki gospodarczej i fiskalnej określanych przez rząd i Sejm, które szczególnie w początkowym okresie dyktowały trudne do osiągnięcia cele inflacyjne.

NBP miał ograniczoną niezależność co do wskazywania celów (dotyczyło to również stosowanych instrumentów). Kolejnymi przyczynami istnienia różnic pomiędzy założonym poziomem inflacji a faktycznie występującym były problemy z właściwym prognozowaniem procesów ekonomicznych i realnością przyjmowanych założeń. Częściowo było to skutkiem dynamiki procesów transformacyjnych, ale również braków w aparacie analitycznym. Wpływał na to również niski stopień rozwoju rynku oraz instrumentów polityki pieniężnej. Z tabeli 2 widać wyraźnie, iż podstawowy obecnie instrument polityki pieniężnej banku centralnego, jakim są stopy procentowe, kształtował się przez pierwsze lata transformacji. Przez pierwsze 4 lata transformacji nie można było stosować polityki zorientowanej na osiągnięcie bezpośrednich celów operacyjnych, wymagało to bowiem odpowiedniego stopnia rozwoju rynku, który umożliwiał użycie właściwych narzędzi ${ }^{33}$. Przyczyny tego stanu rzeczy leżały również poza sferą polityki pieniężnej NBP, a mianowicie we wzroście rezerw dewizowych w latach 1994-1995, spowodowanym nadwyżką w obrotach bieżących bilansu płatniczego oraz napływie kapitałów. Trend odwrócił się w roku

33 Z. Polański, B. Pietrzak, B. Woźniak, op.cit., s. 149. 
1997 i nastąpiło znaczące pogorszenie się obrotów bieżących. Na tę sytuację nałożył się kryzys walutowy w roku 1996 na tzw. rynkach wschodzących.

Tabela 2. Wysokość stóp procentowych NBP w stosunku rocznym w latach 1989-1997

\begin{tabular}{|l|c|c|c|c|}
\hline Rok Stopa & referencyjna & lombardowa & depozytowa & redyskontowa \\
\hline 1989 & - & - & - & 26,0 \\
\hline 1990 & - & - & - & 48,0 \\
\hline 1991 & - & - & - & 36,0 \\
\hline 1992 & - & 37,0 & - & 32,0 \\
\hline 1993 & - & 33,0 & - & 29,0 \\
\hline 1994 & - & 31,0 & - & 28,0 \\
\hline 1995 & - & 28,0 & - & 25,0 \\
\hline 1996 & - & 25,0 & - & 22,0 \\
\hline 1997 & - & 27,0 & - & 24,5 \\
\hline
\end{tabular}

Źródło: http://www.nbp.pl/home.aspx?f=/dzienne/stopy_historyczne.htm, dostęp 4.03.2014.

W połowie lat 90. w sytuacji ustabilizowania kursu walutowego oraz wysokiego poziomu rezerw dewizowych powstały warunki do zmiany zasad kontroli podaży pieniądza przez NBP, który zaproponował nowy zestaw celów. Celem bezpośrednim wciąż pozostawała inflacja, celem pośrednim był przyrost podaży pieniądza ogółem, wreszcie operacyjnym - przyrost podaży pieniądza rezerwowego. Znaczącą zmianą w stosunku do dotychczas przyjętego celu operacyjnego, czyli stabilizacji krótkookresowych stóp procentowych, było określenie go jako wytyczne dotyczące przyrostu pieniądza rezerwowego ${ }^{34}$. Sejm podjął w tej sprawie stosowne uchwały, akceptując założenia polityki pieniężnej na lata 1996-199735. W 1997 r. zrewidowano cele polityki pieniężnej, gdyż stało się oczywiste, że stosowane przez NBP narzędzia (stóp procentowych i stopy rezerwy obowiązkowej) nie wpływają dostatecznie na poziomy stóp banków komercyjnych.

Działaniem, które miało wzmocnić kurs polityki antyinflacyjnej, osłabić oczekiwania inflacyjne i usprawnić obieg pieniężny, stała się operacja denominacji, która została przeprowadzona w $1995 \mathrm{r}$. De facto początek prac nad projektem denominacji ogłosił już w lipcu 1990 r. ówczesny prezes NBP Władysław Baka. Stosunek wymiany wynosił $10000: 1^{36}$, przeliczeniu według tej samej relacji uległy ceny, wszelkie należności, płace, zobowiązania i prawa majątkowe. Zastąpienie złotego (PLZ) nową

34 Raport Roczny NBP 1997, op.cit., s. 13.

35 R. Kokoszczyński, op.cit., s. 235.

36 Ustawa z dnia 7 lipca 1994 r. o denominacji złotego, DzU nr 84, poz. 386. 
jednostką pieniężną (PLN) było nieuniknione z powodu skutków wysokiej inflacji w latach 1989-1990 i późniejszego wzrostu cen. Efektem tych zjawisk była konieczność wprowadzania do obiegu banknotów o coraz wyższych nominałach, w roku:

- 1989 - $20000 \mathrm{zl}, 50000 \mathrm{zł} \mathrm{i} 200000 \mathrm{zł}$,

- 1990 - $100000 \mathrm{zl}, 500000 \mathrm{zl}$,

- 1991 - $1000000 \mathrm{zt}$

- $1992-2000000 \mathrm{z}^{37}$.

Bilon znikł zupełnie $\mathrm{z}$ obiegu, mimo że nie przestał być prawnym środkiem płatniczym, z uwagi na zbyt niską wartość monet (najniższym nominałem w praktyce używanym w obiegu było $50 \mathrm{zł}$ ). W 1994 r. PKB przekroczył 2 tryliony zł, przeciętne wynagrodzenie brutto było wyższe niż $5 \mathrm{mln}$, dolar wart był ponad 24 tys. zł. Postępowała stabilizacja gospodarki, możliwe było przeprowadzenie denominacji, która została określona została ustawą z dnia 7 lipca $1994 \mathrm{r}^{38}$ Nowe regulacje weszły w życie 1 stycznia roku następnego. Przez 2 lata istniała w Polsce dwuwalutowość, ceny podawane były w starych i nowych złotych. Stare znaki pieniężne można było wymienić w placówkach NBP do końca 2010 r. ${ }^{39}$ Denominacja zakończyła się sukcesem, nowy pieniądz został zaakceptowany przez społeczeństwo, choć tendencja do wyrażania wartości utrzymywała się jeszcze przez kilka następnych lat po zakończeniu operacji wymiany.

\section{Polityka pieniężna NBP w latach 1998-2012}

Niezwykle istotnym wydarzeniem dla strategii polityki pieniężnej banku centralnego było ukonstytuowanie się nowego organu statutowego NBP - Rady Polityki Pieniężnej, która przejęła część kompetencji prezesa NBP związanych z kształtowaniem polityki pieniężnej. We wrześniu 1998 r. Rada zdecydowała o wprowadzeniu do polityki pieniężnej strategii tzw. bezpośredniego celu inflacyjnego w odróżnieniu od strategii z przełomu lat 80. i 90., gdy NBP skupiał się na zredukowaniu bardzo wysokiej inflacji oraz przywróceniu równowagi pieniężnej. Stosowano tu głównie kontrolę masy pieniądza w obiegu poprzez korelację do realnego wzrostu produktu krajowego brutto, uwzględniając dynamikę cen ${ }^{40}$. Drugim, jakże istotnym zadaniem banku centralnego była współpraca z rządem w kwestii stabilizacji kursu walutowego (została

37 http://banknotypolskie.pl/banknoty/, dostęp 2.01.2014.

38 Ustawa z dnia 7 lipca 1994 r. o denominacji złotego, op.cit.

39 R. Kokoszczyński, op.cit., s. 214.

40 G. Wójtowicz, A. Wójtowicz, op.cit., s. 177-178, 184-185, 193, 207. 
zdefiniowana jako pośredni cel inflacyjny). Z początku wprowadzono ograniczoną wymienialność złotego, przyjmując system kursu sztywnego, dla przykładu w $1990 \mathrm{r}$. kurs dolara wynosił 9500 zł i był traktowany jako „kotwica antyinflacyjna”. Decyzjom tym towarzyszyło równoczesne złagodzenie ograniczeń w obrocie dewizami ${ }^{41}$.

Polska dążyła do integracji z Unią Europejską, co nie pozostało bez wpływu na politykę pieniężną NBP. Została ona podporządkowana postanowieniom Traktatu z Maastricht, który wyznaczał zasadniczy cel dla narodowych banków centralnych, jakim było zapewnienie niskiego poziomu cen.

Oparcie strategii polityki pieniężnej na systemie tzw. bezpośredniego celu inflacyjnego (BCI) spowodowało, iż zmiany podaży pieniądza przestały być celem polityki pieniężnej (NBP wyznaczał je jako wielkość referencyjną) ${ }^{42}$. Do najważniejszych przyczyn przyjęcia nowej strategii (stosowanej również przez inne banki centralne) należało przekonanie o jej skuteczności $\mathrm{w}$ dokończeniu procesu dezinflacji oraz narastająca niestabilność relacji wiążących zmiany podaży pieniądza z poziomem cen. Znalazło to odbicie w założeniach polityki pieniężnej określonych przez RPP w dokumencie „Średniookresowa strategia polityki pieniężnej na lata 1999-2003”, przyjętym jesienią 1998 r. Średniookresowym celem polityki pieniężnej było obniżenie stopy inflacji do poziomu poniżej $4 \% \mathrm{w}$ roku $2003^{43}$. W lutym RPP przyjęła „Strategię polityki pieniężnej po 2003 r.", w której znalazło się potwierdzenie zasadności stosowania polityki BCI także po zakończeniu procesu dezinflacji. Cel inflacyjny mieścił się w przedziale $2,5 \% \pm 1$ pkt. proc. Stał się on celem założeń polityki pieniężnej przyjmowanych na kolejne lata ${ }^{44}$.Wywołało to odzew środowiska ekonomicznego, które obawiało się, czy takie przeorientowanie celów nie jest zabiegiem zbyt wczesnym ze względu na fakt, iż niska inflacja w latach 2002-2003 była efektem stosunkowo długiego okresu deflacji cen żywności, a ożywienie koniunktury i ponowne odwrócenie szoków podażowych mogłoby utrudnić osiągnięcie celu inflacyjnego ${ }^{45}$.

41 Ustawa z dnia 15 lutego 1989 r. Prawo dewizowe, DzU nr 6, poz. 33.

${ }^{42}$ M. Brzoza-Brzezina, M. Józefowska, Bank centralny - Narodowy Bank Polski, w: Bankowość na świecie $i$ w Polsce. Stan obecny i tendencje rozwojowe, red. L. Oręziak, B. Pietrzak, Olympus, Warszawa 2001, s. 205-206.

${ }^{43}$ Raport Roczny NBP 1998, op.cit., s. 20-21.

${ }^{44}$ Raporty o inflacji z lat 1998-2007 oraz Sprawozdania z wykonania założeń polityki pieniężnej, http:// www.nbp.pl/home.aspx?f=/publikacje/polityka_pieniezna.html, dostęp 9.11.2012.

45 A. Sławiński, Polityka pieniężna w czasie rzeczywistym, w: Ekonomia, społeczeństwo, polityka: studia ofiarowane prof. dr. hab. Januszowi Kalińskiemu w 70. rocznicę urodzin, red. A. Zawistowski, Oficyna Wydawnicza SGH, Warszawa 2012, s. 460. 
Tabela 3. Inflacja i podaż pieniądza Polsce w okresie 1998-2012

\begin{tabular}{|l|c|c|}
\hline \multicolumn{1}{|c|}{ Rok } & Inflacja $(\mathrm{w} \%)$ & Przyrost podaży pieniądza (w mld zł) \\
\hline 1998 & 11,80 & 48,3 \\
\hline 1999 & 7,30 & 34,6 \\
\hline 2000 & 10,10 & 38,1 \\
\hline 2001 & 5,47 & 24,5 \\
\hline 2002 & 1,90 & $-3,7$ \\
\hline 2003 & 0,84 & 17,2 \\
\hline 2004 & 3,49 & 29,5 \\
\hline 2005 & 2,10 & 43,7 \\
\hline 2006 & 1,00 & 77,9 \\
\hline 2007 & 2,50 & 67,9 \\
\hline 2008 & 4,20 & 107,0 \\
\hline 2009 & 3,50 & 42,3 \\
\hline 2010 & 2,60 & 55,8 \\
\hline 2011 & 4,30 & 94,1 \\
\hline 2012 & 3,70 & 40,5 \\
\hline
\end{tabular}

Źródło: Opracowanie własne na podstawie: http://www.nbp.pl/home.aspx?f=/statystyka/pieniezna_i bankowa/m3.html, dostęp 4.03.2014; http://www.stat.gov.pl/gus/5840_1634_PLK_HTML.htm, dostęp 4.03.2014.

W roku 2004 nastąpił skokowy wzrost inflacji, głównie z powodu bardzo silnego wzrostu cen żywności, co było skutkiem wejścia Polski do UE oraz zwyżki cen ropy naftowej na rynkach światowych ${ }^{46}$. RPP podjęła decyzję o podniesieniu stóp procentowych, przykładowo stopa referencyjna wzrosła z 5,75\% do 6,50\% ${ }^{47}$. Decyzje te zostały ocenione krytycznie przez ekonomistów, którzy co prawda podzielali je w projekcji ex ante, uważali je jednak za nie w pełni adekwatne w ujęciu ex post $t^{48}$. Lata 2005-2006 przyniosły niską inflację, Rada musiała zidentyfikować determinanty takiego stanu, przesłankami niskiego poziomu inflacji mogły być globalizacja lub efekt wprowadzenia strategii bezpośredniego celu inflacyjnego ${ }^{49}$. Powyższy okres przyniósł obniżkę stóp procentowych banku centralnego o 1,5 pkt. proc. ${ }^{50}$ Trend inflacyjny odwrócił się w następnych dwóch latach, Rada zareagowała na niego poprzez podniesienie stóp procentowych. Argumenty krytyczne zarzucające spóźnione i nieadekwatne do rozwoju stanu rzeczy pociągnięcia stępiły swe ostrza w obliczu

\footnotetext{
46 Ibidem, s. 461.

47 http://www.nbp.plh/home.aspx?f=/dzienne/stopy_archiwum.htm, dostęp 24.11.2012.

48 A. Sławiński, op.cit., s. 462.

49 Ibidem.

50 http://www.nbp.pl/home.aspx?f=/dzienne/stopy_archiwum.htm, dostęp 24.11.2012.
} 
globalnego kryzysu finansowego ${ }^{51}$. Stopy procentowe spadły w ciągu 7 miesięcy $2009 \mathrm{r}$. o 1,5 pkt. proc., a stopa referencyjna była wyższa od BCI tylko o 1 pkt. proc. W kwestii podaży pieniądza, porównując dane z tabel 1 i 3, widać wyraźnie, że istniejący do momentu powstania RPP, tj. roku 1998 systematyczny trend wzrostowy przyrostu masy pieniądza w obiegu został zahamowany. W 2002 r. doszło nawet do zmniejszenia całkowitej ilości pieniądza w obiegu. Podaż pieniądza jest pod kontrolą, decyzje $\mathrm{w}$ tej dziedzinie podejmowane są w zależności od potrzeb i stanu realizacji strategii polityki pieniężnej.

Rada znalazła się w obliczu presji, by wzorem FED, EBC i Banku Anglii dokapitalizować banki komercyjne, włączając w to emitowane przez nie obligacje. Mimo to nie podjęto takiej decyzji, zauważając, iż polskie banki nie poniosły strat kapitałowych w takich rozmiarach jak zagraniczne, oferując pomoc bankom krajowym w postaci umożliwienia im zawierania transakcji fx swap z NBP ${ }^{52}$.

Tabela 4. Wysokość stóp procentowych NBP w stosunku rocznym w latach 1998-2012

\begin{tabular}{|l|c|c|c|c|}
\hline Rok Stopa & referencyjna & lombardowa & depozytowa & redyskontowa \\
\hline 1998 & 15,50 & 20,00 & - & 18,25 \\
\hline 1999 & 16,50 & 20,50 & - & 19,00 \\
\hline 2000 & 19,00 & 23,00 & - & 21,50 \\
\hline 2001 & 11,50 & 15,50 & 7,50 & 14,00 \\
\hline 2002 & 6,75 & 8,75 & 4,75 & 7,50 \\
\hline 2003 & 5,25 & 6,75 & 3,75 & 5,75 \\
\hline 2004 & 6,50 & 8,00 & 5,00 & 7,00 \\
\hline 2005 & 4,50 & 6,00 & 3,00 & 4,75 \\
\hline 2006 & 4,00 & 5,50 & 2,50 & 4,25 \\
\hline 2007 & 5,00 & 6,50 & 3,50 & 5,25 \\
\hline 2008 & 5,00 & 6,50 & 3,50 & 5,25 \\
\hline 2009 & 3,50 & 5,00 & 2,00 & 3,75 \\
\hline 2010 & 3,50 & 5,00 & 2,00 & 3,75 \\
\hline 2011 & 4,50 & 6,00 & 3,00 & 4,75 \\
\hline 2012 & 4,25 & 5,75 & 2,75 & 4,50 \\
\hline
\end{tabular}

Źródło: http://www.nbp.pl/home.aspx?f=/dzienne/stopy_archiwum.htm, dostęp 4.03.2014.

W realizacji przyjętych strategii NBP stosował wcześniej opisane narzędzia polityki pieniężnej, głównie stopy procentowe (patrz tabela 4), które zmieniano

51 A. Sławiński, op.cit., s. 465.

52 Ibidem, s. 468. 
stosownie do celu inflacyjnego oraz bieżącej sytuacji gospodarczej i monetarnej. Cel inflacyjny osiągnięto dopiero w 2001 r., wcześniej rzeczywista stopa inflacji była wyższa od planowanej. Kosztem polityki dezinflacji było spowolnienie gospodarcze w latach 2001-2002 oraz osłabienie działalności inwestycyjnej, stopa wzrostu PKB spadła z poziomu 4-5\% w latach 1998-2000 do poziomu 1\% w latach 2001-2002, by odbić się w 2003 r. do 3,9\%, a w latach 2006-2007 przekraczać 6\% ${ }^{53}$. NBP zliberalizował swą politykę na skutek spadku koniunktury, któremu towarzyszył silny spadek stopy inflacji, stopy procentowe były stopniowo redukowane. Podwyższono je znów w 2004 r. w warunkach rosnącej presji inflacyjnej, po obniżeniu inflacji nastąpiła ponowna redukcja stóp. Wraz ze stabilizacją rynkową i obniżaniem stóp NBP spadały też stopy banków.

Znaczenie kredytów refinansowych stopniowo spadało w analizowanym okresie, wzrosła natomiast rola kredytów lombardowych i redyskontowych, a tym samym ich stóp. Operacje otwartego rynku nabierały coraz większego znaczenia. Od początku 1998 r. wprowadzano kolejne modernizacje związane z ich stosowaniem, stopy oprocentowania operacji otwartego rynku stały się instrumentem bezpośredniego oddziaływania na rynkowe stopy procentowe ${ }^{54}$.

Zasady obliczania rezerwy obowiązkowej uległy modyfikacji, od września1999 r. stosowano jednolitą stopę dla wszystkich depozytów ${ }^{55}$, obniżając ją sukcesywnie w latach następnych (od 5\% w 1999 r. do 4,5\% w 2002 r. i 3,5\% od października 2003 r.), dodatkowo w roku 2003 środki przechowywane w postaci rezerw zostały oprocentowane. Wysokość rezerwy obowiązkowej pozostawała na tym poziomie przez kilka lat, aż do czerwca 2009 r., kiedy RPP postanowiła obniżyć ją o 0,5 pkt. proc. do $3,0 \%{ }^{56}$. Wysokość rezerwy obowiązkowej powróciła do poziomu 3,5\% w grudniu $2010 \mathrm{r}^{57}$ i pozostała do końca roku 2012 na tym poziomie.

Zasadnicza zmiana polityki kursowej nastąpiła w kwietniu 2000 r., kiedy rząd i RPP podjęły decyzję o całkowitym upłynnieniu kursu. Należy podkreślić, iż było to oficjalne stwierdzenie stanu faktycznego, gdyż w rzeczywistości kurs płynny wszedł w życie na początku 1998 r., kiedy NBP przestał interweniować na rynku w celu stabilizacji kursu złotego na określonym poziomi ${ }^{58}$. Polska waluta pierwszy raz w powojennej historii miała być w pełni kształtowana przez rynek, a kurs walutowy nie był odtąd oficjalnym instrumentem polityki monetarnej. Stabilizację kursu zapewniać

\footnotetext{
53 Mały Rocznik Statystyczny Polski 2008, Zakład Wydawnictw Statystycznych, Warszawa 2008, s. 460.

54 Raport Roczny NBP 1999, op.cit., s. 22.

55 Ibidem, s. 25-26.

$56 \mathrm{http}: / / \mathrm{nbp} . \mathrm{pl} /$ statystyka/instrumenty/instrumenty09.xls, dostęp 7.03.2014.

57 http://nbp.pl/statystyka/instrumenty/instrumenty10.xls, dostęp 7.03.2014.

58 A. Sławiński, op.cit., s. 458.
} 
miał wysoki poziom rezerw dewizowych. Początkowo nie nastąpiły zmiany w obszarze polityki kursowej i mechanizmu ustalania kursu złotego, stosowano wciąż pełzającą dewaluację (obniżano stopę miesięcznej dewaluacji) z dopuszczalnym pasmem wahań kursu rynkowego w stosunku do centralnego kursu NBP (z rozszerzaniem pasma wahań $)^{59}$. W analizowanym okresie polska waluta wciąż ulegała aprecjacji, deprecjacje pojawiały się przejściowo w latach 1999, 2002 i 2003 ${ }^{60}$. Tendencja ta utrzymywała się również w latach 2004-2007, choć należy zauważyć, iż w roku 2006 złoty zyskiwał nieznacznie ${ }^{61}$. W pierwszej połowie 2008 r. z powodu zwiększonego napływu kapitału na rynki wschodzące wielu ekonomistów mówiło o kapitale spekulacyjnym, czy wręcz o ataku na polską walutę, złoty silnie umocnił się wobec dolara i euro, z maksimum przypadającym na sierpień $2008 \mathrm{r}$. W związku z kryzysem na rynku kredytów hipotecznych subprime w USA, który spowodował ogólnoświatowy kryzys finansowy (krach na rynkach finansowych rozpoczął się od momentu ogłoszenia spektakularnego bankructwa amerykańskiego banku inwestycyjnego Lehman Brothers 15 września 2008 r.), nastąpiły problemy z płynnością na światowych rynkach, w czego efekcie złoty zaczął się osłabiaćc2. W 2009 r. osłabienie wartości złotego postępowało, było to widoczne zwłaszcza w I kwartale, choć w drugiej połowie roku nastąpiła jego stopniowa aprecjacja, by pod koniec roku osiągnąć poziom ze stycznia $^{63}$. Tendencja aprecjacji złotego postępowała w roku $2010^{64}$, trend ten odwrócił się w roku następnym, osiągając większe nasilenie w drugiej połowie roku ${ }^{65}$. Rok 2012 przyniósł w pierwszej połowie wahania kursu złotego, w III i IV kwartale zarysował się wyraźny trend wzrostowy, złoty umacniał się ${ }^{66}$. W okresie 2004-2012 kurs złotego wobec euro i dolara amerykańskiego wahał się w przedziale 3,2-4,9 PLN za 1 EUR i odpowiednio 2,03-4,05 PLN za 1 USD, dynamika zmian była odczuwalna zwłaszcza od sierpnia 2008 r. do lutego 2009 r., czyli w pierwszej fazie kryzysu finansowego. Pomimo wysoce niesprzyjających czynników zewnętrznych nie doszło w Polsce do krachu na rynku finansowym, po przejściowych zaburzeniach kurs euro wrócił do przedziału 4,0-4,2 PLN za 1 EUR i 3,0-3,1 PLN za 1 USD.

\footnotetext{
59 Raport Roczny NBP 1998, op.cit., s. 27-28.

60 G. Wójtowicz, op.cit., s. 144.

61 Raport Roczny NBP 2007, NBP, Warszawa 2008, s. 32.

62 Raport Roczny NBP 2008, NBP, Warszawa 2009, s. 31.

63 Raport Roczny NBP 2009, NBP, Warszawa 2010, s. 34.

64 Raport Roczny NBP 2010, NBP, Warszawa 2011, s. 14.

65 Raport Roczny NBP 2011, NBP, Warszawa 2012, s. 35.

66 Raport Roczny NBP 2012, NBP, Warszawa 2013, s. 33.
} 


\section{Podsumowanie}

Do bieżącej sytuacji na rynku przyczyniły się osiągnięcia polityki pieniężnej NBP, przede wszystkim obniżenie inflacji do poziomu kilku procent i zbudowanie waluty o stabilnej wartości, mającej zaufanie Polaków. Przez ostatnie 20 lat Narodowy Bank Polski zyskując pełną podmiotowość i dużą autonomię funkcjonowania, stał się jedną z najważniejszych instytucji państwa, a przez to może stosować instrumenty pozwalające realizować zgodną z wolą jego władz politykę pieniężną i wykonywać zadania zapewniające prawidłowe funkcjonowanie i rozwój systemu bankowego, skutecznie i bezpośrednio wpływać na sytuację na rynku pieniężnym.

Polska posiada sprawnie funkcjonujący rynek pieniężny i nowoczesny system bankowy, podstawą są tu regulacje prawne z konstytucyjnie umocowaną pozycją banku centralnego. Dwadzieścia pięć lat przemian przyniosło wypracowanie modelu działania NBP gwarantującego efektywne działanie banku centralnego, w którym znaczącą rolę odgrywa organ statutowy - Rada Polityki Pieniężnej - kształtujący politykę pieniężną. Sytuacja na rynku pieniężnym w roku 2012 poprawiała się, kurs złotego był stabilny, a jego wartość wzrosła w ciągu dwóch ostatnich kwartałów tegoż roku. Wobec braku oznak jakiegokolwiek kryzysu, czy problemów z płynnością, Rada Polityki Pieniężnej zdecydowała w listopadzie 2012 r. o obniżeniu stóp NBP o 25 pkt. baz.

Negatywne skutki globalnego kryzysu finansowego symbolicznie zapoczątkowanego upadkiem banku Lehman Brothers, a także wcześniejszych jeszcze ataków spekulacyjnych na złotego nie przełożyły się na polski system pieniężny. Ten swoisty egzamin ze stabilności systemu udowodnił, iż polityka oraz system pieniężny w Polsce są prowadzone właściwie, z zachowaniem wszelkich standardów bezpieczeństwa, a system pieniężny jest odporny na działanie negatywnych wpływów zewnętrznych oraz w dobrej kondycji.

W najbliższych latach czeka Polskę przyjęcie wspólnej waluty, konkretne terminy nie zostały jeszcze określone, co w obecnej sytuacji finansów międzynarodowych działa sprzyjająco. To historyczna decyzja, która powinna zostać podjęta bez pośpiechu i zbędnej presji, czemu służy stabilna i uregulowana sytuacja na rynku pieniężnym, sprawdzone i dobrze działające mechanizmy oraz instrumenty, jakie ma w swojej gestii Narodowy Bank Polski. 


\section{The monetary policy of the National Bank of Poland after 1989}

The article discusses the activities of National Bank of Poland during the past twenty-five year and more specifically in the years 1989-2013 with particular emphasis on monetary policy. During this time, the Polish central bank has undergone fundamental change, starting from the position of the so-called monobank, i.e. bank without autonomy in activities, characteristic of planned economy. The article describes the process of transformation of the National Bank of Poland to the role of a central bank operating in a market economy. The paper emphasizes all the important events in the transformation, including building of a two-tier banking system, the gradual replacement of the administrative measures by monetary policy instruments, currency denomination, constitutional guarantees of the role and independence of the National Bank of Poland, creation of the Monetary Policy Council - a departure from the single monetary policy-making in favor of collegiality, changing the monetary policy strategy to direct inflation targeting, bank exchange rates policy, open market operations.

Keywords: National Bank of Poland, NBP, monetary policy, two-tier banking system, Zloty denomination, Monetary Policy Council

\section{La politique monétaire de la Banque nationale de Pologne après 1989}

L'article décrit les activités de la Banque nationale de Pologne au cours des vingtcinq dernières années et plus particulièrement sa politique monétaire dans les années 1989-2013. Durant cette période, la banque centrale polonaise a subi un changement fondamental: elle passe du statut de «monobanque» sans autonomie dans une économie planifiée au statut de banque centrale opérant dans une économie de marché. L’article décrit le processus de cette transformation en mettant en avant les événements importants: le renforcement d'un système bancaire à deux niveaux, le remplacement progressif des mesures administratives par des instruments de politique monétaire, la dénomination de la monnaie, les garanties constitutionnelles concernant le rôle et l'indépendance de la Banque nationale de Pologne, la création du Conseil de la politique monétaire.

Mots-clés: Banque nationale de Pologne, NBP, la politique monétaire, le système bancaire à deux vitesses, la dénomination de złoty, le Conseil de la politique monétaire 


\section{Денежно-кредитная политика Национального банка Польши с 1989 года}

В статье рассматривается деятельность Национального банка Польши за последние двадцать пять лет, особенно в 1989-2013 гг. и в отношении денежно-кредитной политики. В течение этого времени польский центральный банк подвергся кардинальным преображениям, а отправной точкой была ситуация, когда он находился на положении монобанка, что характерно для планово-распределительной экономики, без какой-либо автономии действий. Статья показывает, как Национальный банк Польши становился центральным банком, действующим в условиях рыночной экономики. В работе были учтены все знаковые события во время трансформации, в том числе строительство двухуровневой банковской системы, постепенная замена административных мер инструментами денежно-кредитной политики, деноминация польской валюты, конституционные гарантии роли и независимости Национального банка Польши, создание Совета по денежно-кредитной политике - уход от единоличного права ведения денежно-кредитной политики в пользу коллегиальности, переход к стратегии прямого таргетирования инфляции, политика банка в области обменных курсов, в том числе введение плавающего курса злотого, операции на открытом рынке.

Ключевые слова: Национальный банк Польши, денежно-кредитная политика, двухуровневая банковская система, деноминация польской валюты, Совет по денежно-кредитной политике 